medRxiv preprint doi: https://doi.org/10.1101/2021.04.06.21254174; this version posted April 8, 2021. The copyright holder for this preprint

(which was not certified by peer review) is the author/funder, who has granted medRxiv a license to display the preprint in perpetuity.

All rights reserved. No reuse allowed without permission.

\title{
The impact of the COVID-19 pandemic on gastrointestinal infection trends in England,
} February - July 2020

Authors: Nicola K. Love ${ }^{1,2}$, Alex J. Elliot ${ }^{3,4,5}$, Rachel M Chalmers ${ }^{6,7}$ Amy Douglas $^{8}$, Saheer Gharbia $^{8}$, Jacquelyn McCormick ${ }^{8}$, Helen Hughes ${ }^{3,4,9}$, Roger Morbey ${ }^{3,5}$, Isabel Oliver ${ }^{10,11}$, Roberto Vivancos ${ }^{4,10,12}$ and Gillian Smith ${ }^{3,4,5}$

1. UK Field Epidemiology Training Programme, Public Health England, London, United Kingdom

2. Field Service, North East, and Yorkshire \& Humber, National Infection Service, Public Health England, Newcastle upon Tyne, United Kingdom

3. Real-time Syndromic Surveillance Team, Field Service, National Infection Service, Public Health England, Birmingham, UK B3 2PW

4. National Institute for Health Research Health Protection Research Unit (NIHR HPRU) in Gastrointestinal Infections, Liverpool University, United Kingdom

5. National Institute for Health Research Health Protection Research Unit (NIHR HPRU) in Emergency Preparedness and Response at King's College London, London, United Kingdom.

6. Cryptosporidium Reference Unit, Public Health Wales Microbiology and Health Protection, Singleton Hospital, Swansea SA2 8QA

7. Swansea University Medical School, Swansea University, Singleton Park, Swansea, SA2 8PP

8. Gastrointestinal Pathogens Unit, National Infection Service, Public Health England, London NW9 5EQ

9. Farr Institute@HeRC, University of Liverpool, United Kingdom

10. National Infection Service, Public Health England, London NW9 5HT

11. National Institute for Health Research Health Protection Research Unit (NIHR HPRU) in Behavioural Science and Evaluation, Population Health Sciences, University of Bristol, United Kingdom

12. National Institute for Health Research Health Protection Research Unit (NIHR HPRU) in Emerging and Zoonotic Infections, University of Liverpool, United Kingdom

Correspondence to Nicola K Love: nicola.love@phe.gov.uk 
medRxiv preprint doi: https://doi.org/10.1101/2021.04.06.21254174; this version posted April 8, 2021. The copyright holder for this preprint (which was not certified by peer review) is the author/funder, who has granted medRxiv a license to display the preprint in perpetuity.

All rights reserved. No reuse allowed without permission.

\section{Abstract}

Objective: To establish the impact of the first six months of the COVID-19 outbreak response of gastrointestinal (Gl) infection trends in England.

Design: Retrospective ecological study using routinely collected national and regional surveillance data from eight Public Health England coordinated laboratory, outbreak and syndromic surveillance systems using key dates of UK governmental policy change to assign phases for comparison between 2020 and historic data.

Results: Decreases in GI illness activity were observed across all surveillance indicators as COVID-19 cases began to peak. Compared to the 5-year average (2015-2019), during the first six months of the COVD-19 response, there was a 52\% decrease in Gl outbreaks reported (1,544 vs. 3,208 (95\% Cl: 2,938 - 3,478) and a 34\% decrease in laboratory confirmed cases $(27,859$ vs. 42,495 (95\% Cl: $40,068-44,922)$. Gl indicators began to rise during the first lockdown and lockdown easing, although all remained substantially lower than historic figures. Reductions in laboratory confirmed cases were observed across all age groups and both sexes, with geographical heterogeneity observed in diagnosis trends. Health seeking behaviour changed substantially, with attendances decreasing prior to lockdown across all indicators.

Conclusions: There has been a marked change in trends of Gl infections in the context of the COVID-19 pandemic. The drivers of this change are likely to be multifactorial; while changes in health seeking behaviour, pressure on diagnostic services and surveillance system ascertainment have undoubtably played a role there has likely been a true decrease in the incidence for some pathogens resulting from the control measures and restrictions implemented. This suggests that if some of these changes in behaviour such as improved hand hygiene were maintained, then we could potentially see sustained reductions in the burden of GI illness. 
medRxiv preprint doi: https://doi.org/10.1101/2021.04.06.21254174; this version posted April 8, 2021. The copyright holder for this preprint

(which was not certified by peer review) is the author/funder, who has granted medRxiv a license to display the preprint in perpetuity.

All rights reserved. No reuse allowed without permission.

\section{Strengths and limitations of this study}

- Our findings show that there has been a marked change in the burden of GI infections during the COVID-19 outbreak, and although undoubtably changes to health care and surveillance ascertainment have played a role, there does appear to be a true decrease in incidence. These findings suggest that if effective implementation of infection control measures were maintained, then we could see sustained reductions in the person to person transmission of Gl illness in England.

- This study was strengthened by the triangulation of data from several national and regional-based surveillance systems; using this approach we could determine that the trends observed were consistent across all indicators.

- It has not been possible to definitively differentiate the relative contributions of the reduced ascertainment of $\mathrm{Gl}$ infections versus a true decrease in $\mathrm{Gl}$ disease burden in this study, which an additional focussed analysis could address.

- This analysis includes only the first six-months of the COVID-19 outbreak response, and further longitudinal analyses will be performed to explore this further and assess any change as we move into further phases of the pandemic 
medRxiv preprint doi: https://doi.org/10.1101/2021.04.06.21254174; this version posted April 8, 2021. The copyright holder for this preprint (which was not certified by peer review) is the author/funder, who has granted medRxiv a license to display the preprint in perpetuity.

All rights reserved. No reuse allowed without permission.

\section{Introduction}

The 2019 coronavirus pandemic (COVID-19) has resulted in unparalleled challenges for society [1]. During 2020, the United Kingdom (UK) Government implemented a stepwise series of public health measures designed initially to contain, and then delay transmission of the virus (Figure 1). These measures ranged from public health information campaigns, rapid identification of cases and their contacts and isolation of those contacts in the initial phase of the outbreak (February to Mid-March 2020), with additional measures such as social distancing, education and business closures and enforceable 'lockdown' measures in the delay phase (Mid-March onwards; [2]). Changes to healthcare provision and patient management were implemented concurrently to alleviate pressure on the National Health Service (NHS) and minimise nosocomial transmission of COVID-19 while continuing to provide essential care [2].

There is a growing body of evidence indicating that the COVID-19 pandemic and implemented control measures have had indirect impacts on other health conditions. Substantial decreases have been observed in emergency department (ED) attendances, with decreasing presentation of conditions such as strokes, surgical emergencies and cardiac emergencies, delays to cancer diagnoses, and concerns raised about delayed presentation and associated negative outcomes [3-7]. Less well documented are any indirect effects on communicable diseases, which are often controlled using similar nonpharmaceutical interventions to those implemented in the COVID-19 response [8].

Gastrointestinal (GI) infections are an important infectious cause of morbidity and mortality globally, placing a considerable burden on primary and secondary healthcare services. In England, it is estimated that there are in excess of 17 million cases annually, resulting in over 1 million healthcare consultations and around 90,000 confirmed laboratory diagnoses [9-10]. Transmission of GI pathogens is typically faecal-oral, predominantly though consumption of contaminated food or water, or contact with infected individuals, animals or the contaminated environment and fomites; importance of transmission route varies substantially by pathogen. Control measures implemented during the COVID-19 response including improved hand hygiene, reduced social contact, increased environmental cleaning and closure of premises, all known to be effective in reducing Gl infections, primarily those spread by person-to-person transmission and environmental contamination [8].

Using routinely collected surveillance data from several English surveillance systems coordinated by Public Health England (PHE), this study aimed to establish what impact the first six months of the COVID-19 outbreak response (27 January - 2 August) have had on trends in Gl infections. 
medRxiv preprint doi: https://doi.org/10.1101/2021.04.06.21254174; this version posted April 8, 2021. The copyright holder for this preprint (which was not certified by peer review) is the author/funder, who has granted medRxiv a license to display the preprint in perpetuity.

All rights reserved. No reuse allowed without permission.

\section{Methods}

\section{Surveillance systems}

A retrospective ecological study was conducted by performing secondary analyses on routinely collected national and regional surveillance data from eight national PHE coordinated surveillance systems, detailed in Table 1, and Google Trend data. Systems included outbreak monitoring (HPzone), laboratory notifications Second Generation Surveillance System, (SGSS) and EpiNorth3, and real-time syndromic surveillance [11-13]. Syndromic systems covered the spectrum of severity ranging from the NHS 111 telephone health advice service and routine medical appointments captured in the general practitioner (GP) 'in hours' system (GPIH), to GP 'out of hours', which covers emergency GP appointments for acute or severe illness and the Emergency Department Syndromic Surveillance System (EDSSS), which captures those attending EDs [13].

\section{Time periods}

Extracted data covering weeks 1 to 312020 (30 December 2019 - 2 August 2020), and historic comparator data from weeks 1-31 2015-2019, was split into seven COVID-19 pandemic 'Phases' for comparison, determined by the key dates of UK governmental policy changes implemented during the COVID-19 response (Figure 1). These Phases comprised: Pre-outbreak (Phase 1); Early outbreak (Phase 2); Pre-lockdown (Phase 3); Early lockdown (Phase 4); Late lockdown (Phase 5); Lockdown easing (Phase 6); and Further easing (Phase 7; Table 2).

\section{Data analysis}

Total weekly gastrointestinal outbreaks recorded in HPZone were determined for the seven Phases of 2020 and the 5-year average (2015-2019) with 95\% confidence intervals calculated. HPZone data were further analysed by outbreak setting, PHE region and pathogen (including if the suspected pathogen was laboratory confirmed). Pseudonymised SGSS data for selected laboratory confirmed organisms (Campylobacter spp., Cryptosporidium spp., Shiga-toxin producing E. coli [STEC], Giardia sp., Listeria spp., Norovirus, non-typhoidal Salmonella spp., Shigella spp.) were grouped by week of specimen sample date. Age group specific rates were calculated per 100,000 population using Office National Statistics 2019 England mid-year population estimates [14]. Cumulative regional and local authority rates per 100,000 population were determined for week 1 to 312020 and 
medRxiv preprint doi: https://doi.org/10.1101/2021.04.06.21254174; this version posted April 8, 2021. The copyright holder for this preprint

(which was not certified by peer review) is the author/funder, who has granted medRxiv a license to display the preprint in perpetuity.

All rights reserved. No reuse allowed without permission.

the 5-year average for GI infections reported to SGSS for nine PHE regions (ranging from 2.6 - 9.1 million population) and 150 local authority areas (average population size:

$375,686)$. For geographies, risk ratios and percentage relative effects were calculated, and Pearson's correlation was performed for each local authority area using the cumulative COVID-19 rate per 100,000 population [15].

Syndromic data were analysed as described elsewhere [16] for data between week 1 and week 31 2020, with the same period in 2019 used as a comparator. Google Trend searches were performed for key phrases associated with Gl illness in England, as described previously [17]. A score out of 100 is used to represent relative search interest over the given time period and geography.

EpiNorth3 data were used to compare cases from Phases 2-7, 2020 to historic cases (20152019). A univariate case-case analysis was performed using exposure data, with cases reporting foreign travel excluded from analyses of other exposure categories. Comparisons were made between symptom presentation for historic and current cases. Time periods between onset date and specimen date and specimen date and referral date, and the duration of illness were determined, and a Mann-Whitney U test performed. Data from 2019 and 2020 were used to look at differences in laboratory diagnostic testing methods tests used, to account for the increasing use of molecular based techniques in recent years.

All variables were plotted in a time series together with the weekly 5-year average and superimposed COVID-19 outbreak Phases, unless otherwise specified. Statistical analyses were performed using Stata software version 14.2.

\section{Patient and Public Involvement}

This study used routinely collected surveillance data. Patients were not involved in the development of the research question and outcome measures, the design of the study, the recruitment and conduct of the study. 
medRxiv preprint doi: https://doi.org/10.1101/2021.04.06.21254174; this version posted April 8, 2021. The copyright holder for this preprint (which was not certified by peer review) is the author/funder, who has granted medRxiv a license to display the preprint in perpetuity.

All rights reserved. No reuse allowed without permission.

\section{$\underline{\text { Results }}$}

\section{The changing trends of gastrointestinal infections during the different 'Phases' of the COVID-19 outbreak}

During the first seven months of 2020, 1,544 suspected and laboratory-confirmed GI outbreaks were reported in England, representing a 52\% decrease on the 5-year average for the period (3,208 (95\% Cl: 2,938 - 3,478)). During the 'Pre-outbreak' (Phase 1; weeks 1-4), notified Gl outbreaks were comparable to historic figures (Figure 1 and Supplementary Table 1). From week 7 ('Early outbreak', Phase 2) there was a 22\% decrease in Gl outbreaks (510 outbreaks vs. 5-year average: 651 (95\% Cl: 605-697), with this decreasing trend continuing to an $87 \%$ reduction in Gl outbreaks during 'Late lockdown' (Phase 5; weeks 19-22; 5-year average: 46 vs. 350 outbreaks (95\% Cl: $294-406)$. Reported outbreaks remained substantially lower than historically observed for the duration of the COVID-19 response period.

Historically, around $95 \%$ of suspected or confirmed outbreaks reported in England are attributed to viral Gl pathogens (94\% in 2020; Supplementary Table 1) primarily occurring in health and social care settings. During the COVID-19 response period (Phases 2-7), there was a $62 \%$ reduction in the number of reported suspected and confirmed viral outbreaks (862 vs. 2,239), with significant reductions in parasitic outbreaks (2 vs. 32 (95\% Cl: 21-44); 94\% decrease) and bacterial outbreaks (47\% decrease; 51 vs. 97 outbreaks (95\% Cl: $77-$ 115)). Significant decreases in laboratory confirmed Gl cases also occurred, with 27,859 cases reported between Phases 2 and 7 compared with a 5-year average of 42,495 (95\% Cl: 40,068-44,922; 34\% decrease; Figure 1 and Supplementary Table 1). Decreased reports were apparent from week 10 ('Pre-lockdown'; Phase 3; 11\% decrease), with a low of 2,859 cases reported between weeks 13-18 ('Early lockdown'; Phase 4) representing a 66\% decrease (5-year average: 8,345; (95\% Cl: 7,602-9,088)). Laboratory confirmed cases began to increase from week 16 onwards, mirroring the historic seasonal trend for reported Gl pathogen activity despite numbers remaining significantly lower than average; during the historic peak for laboratory reporting, which occurred during lockdown easing, 4,617 cases were reported compared with the 5-year average of 7,879 (95\% Cl: 7,539-8,219); 41\% decrease).

While the total number of laboratory-confirmed cases was reduced, causative organisms were differently impacted when compared to the five-year average. Norovirus reports were most reduced (5.6\% of all laboratory confirmed reports vs. $9.0 \%)$, with reductions also observed for Salmonella spp. (7.9\% vs. $9.5 \%$ ) and Cryptosporidium spp. (2.8\% vs. $3.9 \%)$. The proportion of laboratory-confirmed cases with Giardia spp. (5.4\% vs. $5.2 \%)$, STEC 
medRxiv preprint doi: https://doi.org/10.1101/2021.04.06.21254174; this version posted April 8, 2021. The copyright holder for this preprint (which was not certified by peer review) is the author/funder, who has granted medRxiv a license to display the preprint in perpetuity.

All rights reserved. No reuse allowed without permission.

(1.2\% vs. $1.2 \%)$ and Listeria spp. ( $0.2 \%$ vs. $0.2 \%)$ during the outbreak period remained comparable, while the proportion of Campylobacter spp. reports were increased $(74 \%$ vs. $68 \%)$.

Reported norovirus cases decreased substantially during Phases 3 and 4 (weeks 11-14; Figure $2 \mathrm{a}$ ), remaining significantly below the 5 -year average to week 31 . A similar trend was observed for Cryptosporidium spp., which contrasted with historic trends where a spike in activity was observed between weeks 14 and 18 (Phase 4; 89 vs. 477 cases (95\%Cl: 323631); Figure 2b). The bacterial pathogens Shigella spp., Salmonella spp. and Campylobacter spp., all showed significant decreases during Phase 3, remained low during Phase 4 but then began to increase during Phase 5, following the 5-year average but with a significantly reduced number of cases reported (Figure $2 \mathrm{~d}, \mathrm{f}, \mathrm{g}$ ). The substantial decreases observed for other pathogens were not seen for STEC (Figure 2e), with activity remaining below or at the lower limit of the 5-year average.

Reductions in laboratory confirmed cases across all pathogens were observed across all age groups and both sexes, with decreases varying from $26 \%$ in children aged 1-9 years to $42 \%$ in females over 80 years (Supplementary Figure 1). Age-specific rates for all age groups sharply decreased during the 'Pre-lockdown' (Phase 3; weeks 10 - 12) with lows observed during 'early lockdown' (Phase 4; weeks 13 - 18; Figure 3). Reporting rates began to increase for all age groups into the Late lockdown period (Phase 5; weeks 19 -22), with infection rates in elderly adults and children under 14 years comparable to the 5 -year average by week 31 .

Geographical differences in laboratory confirmed diagnoses were observed across England's nine regional areas (Figure 4 and Supplementary Figure 2). Prior to the COVID-19 outbreak, Gl laboratory-confirmed cases in all regions were above the regional 5-year average with the highest difference in the North East, London and South East regions. By the 'pre-lockdown Phase' (Phase 3), laboratory diagnoses had decreased below the 5-year average in all but the North East, and by lockdown (Phases 4 and 5), all regions were below historical figures. Lockdown easing (Phases 6 and 7) resulted in small increases in Gl diagnoses across all regions, with the North West (NW) showing the smallest decrease in GI pathogens over the lockdown and easing periods, compared to historical figures. There was a significant correlation between upper tier local authorities showing smaller decreases in GI laboratory reports during the COVID-19 outbreak period (Phases 2-7) and those with highest COVID-19 rates up to week 31 (Pearson's correlation 0.18, $\mathrm{p}=0.03$; Supplementary Figure $3)$. 
medRxiv preprint doi: https://doi.org/10.1101/2021.04.06.21254174; this version posted April 8, 2021. The copyright holder for this preprint (which was not certified by peer review) is the author/funder, who has granted medRxiv a license to display the preprint in perpetuity.

All rights reserved. No reuse allowed without permission.

\section{The contribution of health-seeking behaviour and healthcare provision to changes in reported GI illness during the COVID-19 outbreak}

Observed changes may reflect a real decrease in incidence or may be due to changes to healthcare provision or altered health-seeking behaviour or laboratory testing practices, resulting in reduced surveillance system ascertainment. ED attendances for gastroenteritis (as a proportion of attendances with a diagnostic code) decreased substantially in week 11 to a low in week 14, remaining substantially lower than the 2019 comparator up to week 31 (Figure 5a). Gastroenteritis consultations in GP-out of hours services also decreased during the 'pre-lockdown Phase' (Phase 3; weeks 10 - 12), increasing slightly at around week 26 but again remaining consistently low across the period (Figure 5b). A similar trend was also observed for gastroenteritis consultations to GP-in hours services (Figure $5 c$ ). Finally, calls to the NHS 111 helpline for diarrhoea and vomiting combined began to decrease from week 8 to a low at around week 12 (Figure $5 \mathrm{~d}$ ). Calls showed a gradual increase over time, remaining substantially lower than calls observed in 2019. There were no differences in the observed trends for diarrhoea or vomiting as separate symptoms (Supplementary Figure 7).

Decreases in GP-in hours consultations were predominantly observed in younger age groups with substantially decreased age-specific rates seen for children under 14 years during the 'pre-lockdown Phase' (Phase 3), and rates remaining low to week 31

(Supplementary Figure 5). More modest decreases were observed at week 11 for adults and the elderly, with consultation rates remaining stable during lockdown and lockdown easing. Trends for PHE regions (rate per 100,000 population) were comparable, with decreases for all regions in the 'pre-lockdown Phase' and slight increases during lockdown easing (Supplementary Figure 6).

Enhanced specimen and exposure information was obtained from EpiNorth3 for laboratory confirmed North East cases. During the outbreak period, 228 cases were reported compared with 2,225 between 2015 and 2019 (74\% and 80\% with a recorded onset date, respectively). There was no difference in the time between onset date and specimen date for cases reported in Phase 2-Phase 7 2020, compared with historic cases (7 days IQR: 3-14 vs. 7 days (4-12 days); Wilcoxon rank sum $p=0.600$ ), with onset to specimen time comparable across the seven Phases of the COVID-19 outbreak. The time between specimen date and referral date and proportion of samples processed by culture (76.5\% vs. $75.7 \%)$ and molecular techniques (17.2\% vs. $15.5 \%$ ) were also comparable. However, the proportion of specimens processed by light microscopy (protozoa) decreased (2.3\% vs. $7.6 \%)$. The proportion of specimens submitted by general practitioners was $60.2 \%$ compared with $61.3 \%$ 
medRxiv preprint doi: https://doi.org/10.1101/2021.04.06.21254174; this version posted April 8, 2021. The copyright holder for this preprint (which was not certified by peer review) is the author/funder, who has granted medRxiv a license to display the preprint in perpetuity.

All rights reserved. No reuse allowed without permission.

historically, while a small decrease was observed in specimens from EDs (5.1\% vs. $8.4 \%)$ and a small increase from hospital inpatients (29.6\% vs. $25.2 \%)$.

Analysing EpiNorth3 data it was possible to explore illness duration and symptoms for cases with a completed surveillance questionnaire ( $n=179$ [2020]; $n=1870$ [2015-2020]). The proportion of current cases and historic cases reporting diarrhoea ( $40 \%$ vs.38\%) and vomiting (39\% vs. $42 \%$ ) were comparable, with an increase in cases reporting bloody diarrhoea in 2020 (24\% vs. 16\%). When comparing 2020 to historic cases, there was no difference in the duration of illness (7.5 days IQR: 5-12 vs. 8 days (6-12 days); Wilcoxon rank sum $\mathrm{p}=0.980$ ), however as most cases are symptomatic when interviews are performed ( $26 \%$ of current and historic cases), completion of this field is low.

\section{The contribution of population behavioural change to impacts of COVID-19 on GI illness}

Using EpiNorth3 data it was possible to look at changes in exposures for cases of Gl illness reported in North East England during the COVID-19 outbreak period and historically (Phase 2-7; 2020: 79\% cases reported exposure; $n=230$ vs. historic cases: reported between 2015 and $2019 ; 84 \%$ cases reported exposure; $n=2,501)$. The odds of cases with a Gl diagnosis reporting foreign travel were significantly reduced in 2020 (OR: 0.37; (95\% Cl: 0.23-0.57); $\mathrm{p}=<0.001)$, and there were also significant decreases in the odds of cases reporting exposures to UK visitor attractions (OR: 0.23 ; (95\% Cl: $0.05-0.70) ; p=0.006)$ and recreational water exposure in the UK, which includes swimming pools (OR: 0.58 ; $(95 \% \mathrm{Cl}$ : 0.34-0.94); $p=0.024)$. Salmonella and Cryptosporidium cases had significantly lower odds of reporting UK food outlet exposures (OR: 0.5 and 0.4 respectively, $p=0.03$ for both).

Trends in outbreak reporting could also be attributed in part to behavioural change. Significant reductions in health and social care outbreaks caused by all pathogens were observed from the 'early pandemic Phase' (Phase 2) of the COVID-19 response, with 318 care home outbreaks (vs. 5-year average: 402 (95\% Cl: 355-448)) and 45 healthcare setting outbreaks reported (vs. 89 (95\% Cl:75-103); Figure 5). In educational settings, the number of outbreaks was comparable to the 5-year average in Phase 2, with a decrease observed in Phase 3, prior to school closures (53 outbreaks vs. 86 (95\% Cl: 70-102)). Outbreaks in educational settings remained low following the reopening of schools for specific age groups ( 25\% of pupils) in week 23 (Phase 6; 3 vs. 61 outbreaks (95\% Cl: 37-84)), with the number of outbreaks increasing during Phase 7 (10 vs. 51 outbreaks (95\% Cl: 39-64)). Outbreaks associated with food outlets also reduced significantly in Phase 3, prior to the lockdown period (3 vs. 13 (95\% Cl: 9-17)) and remained low until Phase 7 when pubs and restaurants reopened for dine-in customers (6 vs. 13 (95\% Cl: 9-17)). Outbreaks classified as 'other', 
medRxiv preprint doi: https://doi.org/10.1101/2021.04.06.21254174; this version posted April 8, 2021. The copyright holder for this preprint (which was not certified by peer review) is the author/funder, who has granted medRxiv a license to display the preprint in perpetuity.

All rights reserved. No reuse allowed without permission.

which included visitor attractions, were substantially decreased in Phase 4, when outbreaks associated with such settings are historically highest (7 vs. 51 (95\% Cl: 44-57)).

Finally, evidence from Google Trends data showed searches for GI associated phrases such as 'Food poisoning', 'gastroenteritis' and 'sickness bug' all decreased dramatically between week 11 and week 13, while trends for 'handwashing' and 'disinfection' increased substantially between week 8 and week 14, mirroring decreases observed in other surveillance systems (Supplementary Figure 8).

\section{Discussion}

Analysis of routinely collected surveillance data from England's main laboratory, outbreak and syndromic surveillance systems showed marked changes in Gl infection trends during the first six months of the COVID-19 outbreak response. Decreases in GI activity were observed across all surveillance indicators as restrictions were implemented in line with increasing COVID-19 activity [15]. As COVID-19 cases increased and further restrictions were implemented, health-seeking behaviour changed dramatically in England, with health service attendances decreasing from week 12 across all syndromic indictors [1, 18-22]. Similar decreases were observed internationally, with speculation that reduced healthcare usage was due to public avoidance, with some evidence that those with milder symptoms were least likely to seek care [3-7, 23]. However, behavioural surveys conducted during late lockdown and lockdown easing found $70-80 \%$ of participants had continued to seek care, if needed [24-25]. Protecting the health system was cited as a reason for healthcare avoidance by $16 \%$ of respondents with symptoms, while $10 \%$ of individuals reported difficulties in accessing their GP for physical complaints [24-25]. In England, a government information campaign was launched from week 17 to encourage the public to continue to seek care, particularly for severe or acute conditions [2]; however, our study shows that GI activity was increasing prior to this. Many syndromic indicators, such as those for noninfectious gastrointestinal conditions, rapidly returned to baseline levels during lockdown and easing, while gastrointestinal infections showed more modest increases [18-21].

Behavioural studies undertaken during the first wave suggest good adherence to hygiene and social distancing measures by the population $[25,26]$, raising the possibility that widespread infection prevention and hygiene measures implemented during the COVID-19 response have had protective effects to varying degrees dependant on the pathogen and transmission route of GI pathogens. Indeed, evidence suggests that non-pharmaceutical interventions implemented in the response were associated with reductions in influenza activity during the $2019 / 20$ season [27-29]. As with influenza, viral gastroenteritis activity is 
medRxiv preprint doi: https://doi.org/10.1101/2021.04.06.21254174; this version posted April 8, 2021. The copyright holder for this preprint (which was not certified by peer review) is the author/funder, who has granted medRxiv a license to display the preprint in perpetuity.

All rights reserved. No reuse allowed without permission.

higher during winter, with outbreaks predominantly associated with person-to-person transmission in health and social care settings; in the 2019/20 season, this outbreak activity appeared to have been partially curtailed by the COVID-19 response. Enhanced infection control measures were recommended in closed settings during week 8 [2]; although there was evidence that measures were not being sufficiently implemented until later in the response [30]. Reports of outbreaks in food outlet and education settings were also reduced prior to closures announced as part of social distancing measures, and all surveillance indicators remained significantly lower than average despite the partial reopening of schools, restaurants and overseas travel corridors during the lockdown easing phase [2].

There was evidence that those pathogens spread predominantly by person-to-person transmission, such as norovirus and Shigella spp., showed greater reductions, while bacterial pathogens, which are more commonly foodborne and therefore less influenced by hygiene and social distancing measures, were least impacted [8, 31]. It is possible that those individuals with the most severe and prolonged infections, which tend to be bacterial, were more likely to access care, as seen with other diseases [4,6,8,9]. However, a true decrease in activity was plausible given the measures implemented. Salmonella activity was likely substantially reduced by government guidance on non-essential foreign travel, in place from week 12 [2, 32]. Campylobacter, which is usually foodborne and often associated with incorrect food preparation was less impacted than other Gl pathogens, although possible explanations for reductions may include food business closures and improved hygiene limiting the risk of cross-contamination. Cryptosporidiosis has strong seasonality with two peaks, one in late spring associated with $C$. parvum which occurs around lambing season and is often associated with petting farm outbreaks, which were closed as part of the COVID response, and the other, usually larger peak in late summer-early autumn mainly caused by C. hominis linked to increased recreational water use and foreign travel [33]. However, in 2020, C. hominis cases were virtually absent (Cryptosporidium Reference Unit data). It is likely that the closure of premises such as swimming pools and open farms have played a considerable role in this decline, and their reopening may impact on disease transmission.

Reasons for the changes in the national picture observed for Gl infections are likely to be complex and multifactorial, and it is not possible to attribute them to a specific cause. This study was strengthened by the triangulation of data from several surveillance systems; using this approach we could determine that the trends observed were consistent across all indicators. However, while this study has incorporated large national and regional-based surveillance systems, this is not comprehensive and there are other examples of operational GI surveillance systems which have not been included in this study. For example, the PHE 
medRxiv preprint doi: https://doi.org/10.1101/2021.04.06.21254174; this version posted April 8, 2021. The copyright holder for this preprint

(which was not certified by peer review) is the author/funder, who has granted medRxiv a license to display the preprint in perpetuity.

All rights reserved. No reuse allowed without permission.

eFOSS system monitors foodborne and non-foodborne Gl outbreaks across England, however, due to a small number of outbreaks reported by the system it was felt that these data were not sufficiently powered to add to the overall findings of the study [34]. There are further limitations to this work; it has not been possible to definitively differentiate the relative contributions of the reduced ascertainment of $\mathrm{Gl}$ infections versus a true decrease in GI disease burden in this study, which an additional focussed analysis could address. An additional limitation of this study is that negative results are not captured by the SGSS laboratory surveillance system, therefore it was not possible to determine to what degree the changes were due to changes in testing. We were not able to calculate the positivity rate to assess whether only severe cases were being tested, although evidence from the North East suggested that symptomatology was comparable between 2020 cases and historic cases. Guidance was released in week 13 recommending the cessation of routine culture for nonbloody diarrhoea might be considered if laboratories were struggling to deliver the service [35]. However, by then laboratory confirmed cases were beginning to increase again, while other contemporaneous changes implemented to Gl laboratory testing methods, such as the introduction of molecular methods could differentially affect ascertainment of GI pathogens. Furthermore, the smallest decreases in laboratory confirmed GI infections were observed in the North West and North East regions, which had the highest cumulative rates of COVID-19 over this time period [15], suggesting either increased laboratory capacity for both the identification of COVID-19 and GI infections, or less effective implementation of COVID-19 control measures resulting in greater spread of GI infections and COVID-19.

This comprehensive review of PHE surveillance data demonstrates a marked change in GI infection trends in the context of the COVID-19 epidemic. The change is likely to be multifactorial; changes to health seeking behaviour have undoubtedly played a significant role in the trends observed, and ascertainment through surveillance systems has likely been affected. However, from our observations it appears that there has probably also been a true decrease in the incidence of $\mathrm{Gl}$ infections most likely associated with control measures for the COVID-19 epidemic, although the extent of the true decrease cannot be fully estimated in light of the multiple influencing factors identified and the variation in the ecology and epidemiology of GI pathogens and transmission routes. The findings of this study show the importance of multiple surveillance systems to allow for the comparative analysis across multiple indicators in order to overcome the negative impact of a pandemic situation on national surveillance systems and allow us to see the effects. Secondly, because they suggest that if measures such as improved hand hygiene and the effective implementation of infection prevention and control measures in health and social care settings were maintained, then it is possible to see sustained reductions in the burden of Gl illness [30]. 
medRxiv preprint doi: https://doi.org/10.1101/2021.04.06.21254174; this version posted April 8, 2021. The copyright holder for this preprint (which was not certified by peer review) is the author/funder, who has granted medRxiv a license to display the preprint in perpetuity.

All rights reserved. No reuse allowed without permission.

This analysis includes only the first six-months of the COVID-19 outbreak response, and further longitudinal analyses will be performed to explore this further and assess any change as we move into further phases of the pandemic including the relaxation of social distancing measures, further lockdown measures, and the usual winter outbreak period. 
medRxiv preprint doi: https://doi.org/10.1101/2021.04.06.21254174; this version posted April 8, 2021. The copyright holder for this preprint (which was not certified by peer review) is the author/funder, who has granted medRxiv a license to display the preprint in perpetuity.

All rights reserved. No reuse allowed without permission.

\section{References}

1. Elliot AJ, Harcourt SE, Hughes HE, et al. The COVID-19 pandemic: a new challenge for syndromic surveillance. Epidemiol Infect. 2020;148:e122.

doi:10.1017/S0950268820001314

2. Dunn $\mathrm{P}$, Allen L, Cameron G, et al. Covid-19 policy tracker: a timeline of national policy and health system responses to covid-19 in England. 2020. Available at: https://www.health.org.uk/news-and-comment/charts-and-infographics/covid-19policy-tracker Accessed 18 November 2020.

3. Castagneto-Gissey L, Casella G, Russo MF, et al. Impact of COVID-19 outbreak on emergency surgery and emergency department admissions: an Italian level 2 emergency department experience. Br J Surg. 2020;10.1002/bjs.11813. doi:10.1002/bjs.11813

4. Perry R, Banaras A, Werring DJ, et al. What has caused the fall in stroke admissions during the COVID-19 pandemic? J Neurol. 2020;1-2. doi:10.1007/s00415-02010030-

5. Ahuja S, Shah P, Mohammed R. Impact of COVID-19 pandemic on acute spine surgery referrals to UK tertiary spinal unit: any lessons to be learnt? Brit J Neurosurg, 2020. DOI:10.1080/02688697.2020.1777263

6. Hughes HE, Hughes TC, Morbey R, et al. Emergency department use during COVID19 as described by syndromic surveillance. Emerg Med J 2020; 37:600-604.

7. Moroni F, Gramegna M, Ajello S, et al. Collateral damage: Medical care avoidance behavior among patients with myocardial infarction during the COVID-19 pandemic. JACC: Case Reports. 2020. doi:10.1016/j.jaccas.2020.04.010

8. Hawker J, Begg N, Blair I, et al. (2005) Communicable Disease. Control Handbook. Second Edition. Blackwell Publishing.

9. Tam CC, Rodrigues LC, Viviani L, et al. Longitudinal study of infectious intestinal disease in the UK (IID2 study): incidence in the community and presenting to general practice. Gut. 2012. 61(1):69

10. Public Health England. Routine reports of gastrointestinal infections in humans, England and Wales. Health Protection report. 2020. 14(2). Available: https://assets.publishing.service.gov.uk/government/uploads/system/uploads/attachm ent data/file/861041/hpr0220 Gls.pdf. Accessed 18 November 2020.

11. Kara-Zaïtri C, Gelletlie R, Schweiger M. The development and deployment of a national web-based system for communicable disease control in England. Int. J. Infect. Dis. 2012; 16:e133.

12. Public Health England. (2016) Laboratory reporting to Public Health England. Available:https://assets.publishing.service.gov.uk/government/uploads/system/upload s/attachment data/file/739854/PHE Laboratory Reporting Guidelines.pdf

13. Smith GE, Elliot AJ, Lake I, et al. Syndromic surveillance: two decades experience of sustainable systems - its people not just data! Epidemiol Infect. 2019;147:e101. doi:10.1017/S0950268819000074 
medRxiv preprint doi: https://doi.org/10.1101/2021.04.06.21254174; this version posted April 8, 2021. The copyright holder for this preprint (which was not certified by peer review) is the author/funder, who has granted medRxiv a license to display the preprint in perpetuity.

All rights reserved. No reuse allowed without permission.

14. Office for National Statistics (2020) Estimates of the population for the UK, England and Wales, Scotland and Northern Ireland. Available at:

https://www.ons.gov.uk/peoplepopulationandcommunity/populationandmigration/pop ulationestimates/datasets/populationestimatesforukenglandandwalesscotlandandnort hernireland. Accessed 22 November 2020.

15. Public Health England (2020) Weekly COVID-19 surveillance report. Available at: https://assets.publishing.service.gov.uk/government/uploads/system/uploads/attachm ent data/file/907954/Weekly COVID19 Surveillance Report week 32 2.pdf. Accessed 22 November 2020.

16. Bawa Z, Elliot AJ, Morbey RA, et al. Assessing the Likely Impact of a Rotavirus Vaccination Program in England: The Contribution of Syndromic Surveillance. Clin Infect Dis. 2015;61(1):77-85. doi:10.1093/cid/civ264

17. Osuka H, Hall AJ, Wikswo ME, et al. Temporal Relationship Between HealthcareAssociated and Nonhealthcare-Associated Norovirus Outbreaks and Google Trends Data in the United States. Infect Control Hosp Epidemiol. 2018 ;39(3):355-358. doi: 10.1017/ice.2017.322.

18. Public Health England (2020) Remote Health Advice Syndromic Surveillance System weekly report. Available at: https://www.gov.uk/government/collections/syndromicsurveillance-systems-and-analyses\#remote-health-advice-syndromic-surveillancesystem.Accessed 18 November 2020.

19. Public Health England (2020) GP In Hours Syndromic Surveillance System weekly report. Available at:

https://www.gov.uk/government/collections/syndromic-surveillance-systems-andanalyses\#gp-in-hours-syndromic-surveillance-system. Accessed 22 November 2020.

20. Public Health England (2020) GP Out of Hours Syndromic Surveillance System weekly report. Available at: https://www.gov.uk/government/collections/syndromicsurveillance-systems-and-analyses\#gp-out-of-hours-syndromic-surveillance-system. Accessed 22 November 2020.

21. Public Health England (2020) Emergency Department Syndromic Surveillance System weekly report. Available at:

https://www.gov.uk/government/collections/syndromic-surveillance-systems-andanalyses\#emergency-department-syndromic-surveillance-system. Accessed 22 November 2020.

22. Majeed A, Maile EJ, Bindman AB. The primary care response to COVID-19 in England's National Health Service. J R Soc Med. 2020;113(6):208-210. doi:10.1177/0141076820931452

23. Hartnett KP, Kite-Powell A, DeVies J, et al. Impact of the COVID-19 Pandemic on Emergency Department Visits - United States, January 1, 2019-May 30, 2020. MMWR Morb Mortal Wkly Rep. 2020;69(23):699-704.

24. Office for National Statistics Coronavirus and the social impacts on Great Britain: 7 August 2020. 2020. Available at: 
medRxiv preprint doi: https://doi.org/10.1101/2021.04.06.21254174; this version posted April 8, 2021. The copyright holder for this preprint (which was not certified by peer review) is the author/funder, who has granted medRxiv a license to display the preprint in perpetuity.

All rights reserved. No reuse allowed without permission.

https://www.ons.gov.uk/peoplepopulationandcommunity/healthandsocialcare/healtha ndwellbeing/bulletins/coronavirusandthesocialimpactsongreatbritain/7august2020. Accessed 22 November 2020.

25. YouGov and Imperial College London. COVID-19 behaviour tracker. 2020. Available at: http://www.coviddatahub.com/. Accessed 22 November 2020.

26. Fancourt D, Bu F, Mak Wan H, et al. Covid-19 Social Study: results release 17. 2020. Available at: https://b6bdcb03-332c-4ff9-8b9d28f9c957493a.filesusr.com/ugd/3d9db5 8f72d734373243f68867ad8465fb9588.pdf

27. Cowling BJ, Ali ST, Ng TWY, et al. Impact assessment of non-pharmaceutical interventions against coronavirus disease 2019 and influenza in Hong Kong: an observational study. Lancet Public Health. 2020;5(5):e279-e288. doi:10.1016/S24682667(20)30090-6

28. Itaya T, Furuse $Y$, Jindai K. Does COVID-19 infection impact on the trend of seasonal influenza infection? 11 countries and regions, from 2014 to 2020 . Int J Infect Dis. 2020; 97:78-80. doi:10.1016/j.jij.2020.05.088

29. Melidou A, Pereyaslov D, Hungnes $O$, et al. Virological surveillance of influenza viruses in the WHO European Region in 2019/20 - impact of the COVID-19 pandemic. Euro Surveill. 2020;25(46):pii=2001822. https://doi.org/10.2807/15607917.ES.2020.25.46.2001822

30. The Centre for Evidence-based Medicine: How can pandemic spreads be contained in care homes? 2020. Available at: https://www.cebm.net/covid-19/how-canpandemic-spreads-be-contained-in-care-homes/. Accessed 22 November 2020.

31. Nichols GL, Richardson JF, Sheppard SK, et al. Campylobacter epidemiology: a descriptive study reviewing 1 million cases in England and Wales between 1989 and 2011. BMJ Open. 2012;2(4):e001179. Published 2012 Jul 12. doi:10.1136/bmjopen2012-001179

32. O'Brien SJ. The "decline and fall" of nontyphoidal salmonella in the United kingdom. Clin Infect Dis. 2013;56(5):705-710. doi:10.1093/cid/cis967

33. Cacciò SM, Chalmers RM. Human cryptosporidiosis in Europe. Clin Microbiol Infect. 2016;22(6):471-480. doi:10.1016/j.cmi.2016.04.021

34. Public Health England. Foodborne and non-foodborne gastrointestinal outbreaks surveillance. Available at: https://www.gov.uk/guidance/foodborne-and-nonfoodborne-gastrointestinal-outbreaks-surveillance. Accessed 22 November 2020.

35. NHS England and NHS Improvement. Recommendations from RCPath and Professional Bodies (IBMS ACP and ACB) Prioritisation/deferral of Pathology Laboratory Work in light of SARS CoV 2 (COVID19) epidemic Version1.1. 2020./ Available at: http://www.acb.org.uk/whatwesay/acb newspage/2020/04/03/covid-19--recommendations-for-laboratory-work. Accessed 22 November 2020. 
medRxiv preprint doi: https://doi.org/10.1101/2021.04.06.21254174; this version posted April 8, 2021. The copyright holder for this preprint

(which was not certified by peer review) is the author/funder, who has granted medRxiv a license to display the preprint in perpetuity.

All rights reserved. No reuse allowed without permission.

\section{Contributorship statement}

N.L., S.G., I.O and G.S. designed the study. N.L. analysed the data, with support from A.E., A.D., G.S., H.H., and R.M. R.C., A.D., S.G., J.M., and R.V. contributed to the interpretation of the results. N.L., A.E, and G.S. wrote the manuscript with input from all authors.

\section{Acknowledgements}

The authors acknowledge the contribution and support from all data providers including: NHS 111 and NHS Digital; QSurveillance ${ }^{\circledR}$, University of Oxford, EMIS/EMIS practices, ClinRisk $\circledast$, TPP, ResearchOne and participating SystmOne GP practices; Advanced and the participating $\mathrm{OOH}$ service providers; participating EDSSS emergency departments, Royal College of Emergency Medicine; North East, North West, Yorkshire, East Midlands, West Midlands, East of England, London, South East Coast, South Central, and South Western NHS Ambulance Trusts and The Association of Ambulance Chief Executives. The authors also wish to thank Petra Manley, Katri Jalava and Lesley Larkin for comments and Claire Ferraro, Lucy Findlater and Adrian Wensley for technical support.

\section{Ethical approvals}

Ethical approval was not required for this study. The authors affirm that the manuscript is an honest, accurate, and transparent account of the study being reported; that no important aspects of the study have been omitted; and that any discrepancies from the study as originally planned have been explained.

\section{Funding}

AJE, RV, $\mathrm{HH}$, and GES receive support from the National Institute for Health Research Health Protection Research Unit (NIHR HPRU) in Gastrointestinal Infections, IO receives support from the NIHR HPRU in Behavioural Science and Evaluation. GES, RM and AJE receive support from the NIHR HPRU in Emergency Preparedness and Response. The views expressed are those of the author(s) and not necessarily those of the NIHR, Public Health England or the Department of Health and Social Care. Funding was not applicable to this study.

\section{Data sharing}

No additional data available 
Table 1- PHE Surveillance syll rights resery and ind reuse allowed without nermission. infection surveillance

\begin{tabular}{|c|c|c|c|}
\hline System & Coverage & Reporting statistic & Indictor \\
\hline HPzone & $\begin{array}{l}\text { National (by PHE } \\
\text { regional centre) }\end{array}$ & $\begin{array}{l}\text { Statutory notifications of } \\
\text { suspected or confirmed } \\
\text { outbreaks of food } \\
\text { poisoning, haemolytic } \\
\text { uraemic syndrome (HUS) } \\
\text { and infectious bloody } \\
\text { diarrhoea. } \\
\text { Outbreaks of gastroenteritis } \\
\text { in closed settings. }\end{array}$ & $\begin{array}{l}\text { Food poisoning; } \\
\text { HUS; } \\
\text { Infectious bloody diarrhoea. } \\
\text { GI illness in closed settings } \\
\text { (Care homes, schools, } \\
\text { prisons) }\end{array}$ \\
\hline EpiNorth3 & $\begin{array}{l}\text { North East England } \\
\text { residents (approx. } \\
2.6 \text { million } \\
\text { population) }\end{array}$ & $\begin{array}{l}\text { Notifiable infections } \\
\text { reported in North East } \\
\text { England linked with } \\
\text { enhanced exposure } \\
\text { information from routine } \\
\text { surveillance questionnaires } \\
\text { conducted by } \\
\text { environmental health } \\
\text { officers for selected } \\
\text { organisms. }\end{array}$ & $\begin{array}{l}\text { Specified Gl pathogens: } \\
\text { Cryptosporidium, Shiga toxin } \\
\text { producing E. coli (STEC), } \\
\text { Giardia, Salmonella, Shigella }\end{array}$ \\
\hline $\begin{array}{l}\text { SGSS (Second } \\
\text { Generation } \\
\text { Surveillance } \\
\text { System) }\end{array}$ & $\begin{array}{l}\text { All NHS laboratories } \\
\text { in England }\end{array}$ & $\begin{array}{l}\text { Routine laboratory } \\
\text { notifications from NHS } \\
\text { laboratories including } \\
\text { statutory notifications of } \\
\text { laboratory confirmed } \\
\text { notifiable organisms. }\end{array}$ & $\begin{array}{l}\text { Specified GI pathogens: } \\
\text { Campylobacter, } \\
\text { Cryptosporidium, E. coli } \\
\text { (STEC), Giardia, Listeria, } \\
\text { Norovirus, non-typhoidal } \\
\text { Salmonella, Shigella }\end{array}$ \\
\hline NHS 111 & National, England & Calls for indicator & Diarrhoea, Vomiting \\
\hline GP in hours & $\begin{array}{l}\text { Approximately } 4,000 \\
\text { GP practices in } \\
\text { England }\end{array}$ & $\begin{array}{l}\text { In-hours (weekdays, } \\
\text { daytime) GP consultation } \\
\text { rates per } 100,000 \\
\text { registered patients }\end{array}$ & $\begin{array}{l}\text { Gastroenteritis - clinical } \\
\text { diagnoses, } \\
\text { Diarrhoea and Vomiting }\end{array}$ \\
\hline GP out of hours & $\begin{array}{l}\text { Approximately } 60 \% \\
\text { coverage of GP out- } \\
\text { of-hours activity in } \\
\text { England }\end{array}$ & $\begin{array}{l}\text { Out-of-hours and } \\
\text { unscheduled care } \\
\text { consultations for indicator } \\
\text { as a percentage of total } \\
\text { read-coded consultations }\end{array}$ & $\begin{array}{l}\text { Gastroenteritis - clinical } \\
\text { diagnoses, } \\
\text { Diarrhoea and Vomiting }\end{array}$ \\
\hline $\begin{array}{l}\text { Emergency } \\
\text { Department (ED) }\end{array}$ & $\begin{array}{l}\text { Sentinel system. } 80 \\
\text { EDs across England }\end{array}$ & $\begin{array}{l}\text { Percentage of emergency } \\
\text { department visits with a } \\
\text { recorded diagnosis code. }\end{array}$ & $\begin{array}{l}\text { Gastroenteritis - clinical } \\
\text { diagnoses, }\end{array}$ \\
\hline
\end{tabular}


medRxiv preprint doi: https://doi.org/10.1101/2021.04.06.21254174; this version posted April 8, 2021. The copyright holder for this preprint (which was not certified by peer review) is the author/funder, who has granted medRxiv a license to display the preprint in perpetuity.

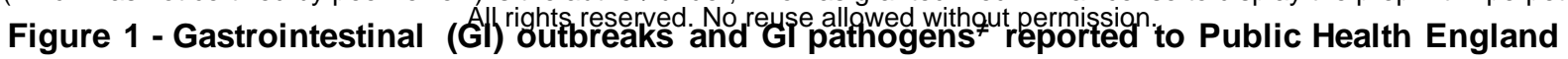
between Week 1 and Week 312020 and the 5-year weekly average (95\% confidence interval), indicating key public health measures introduced during the COVID-19 response

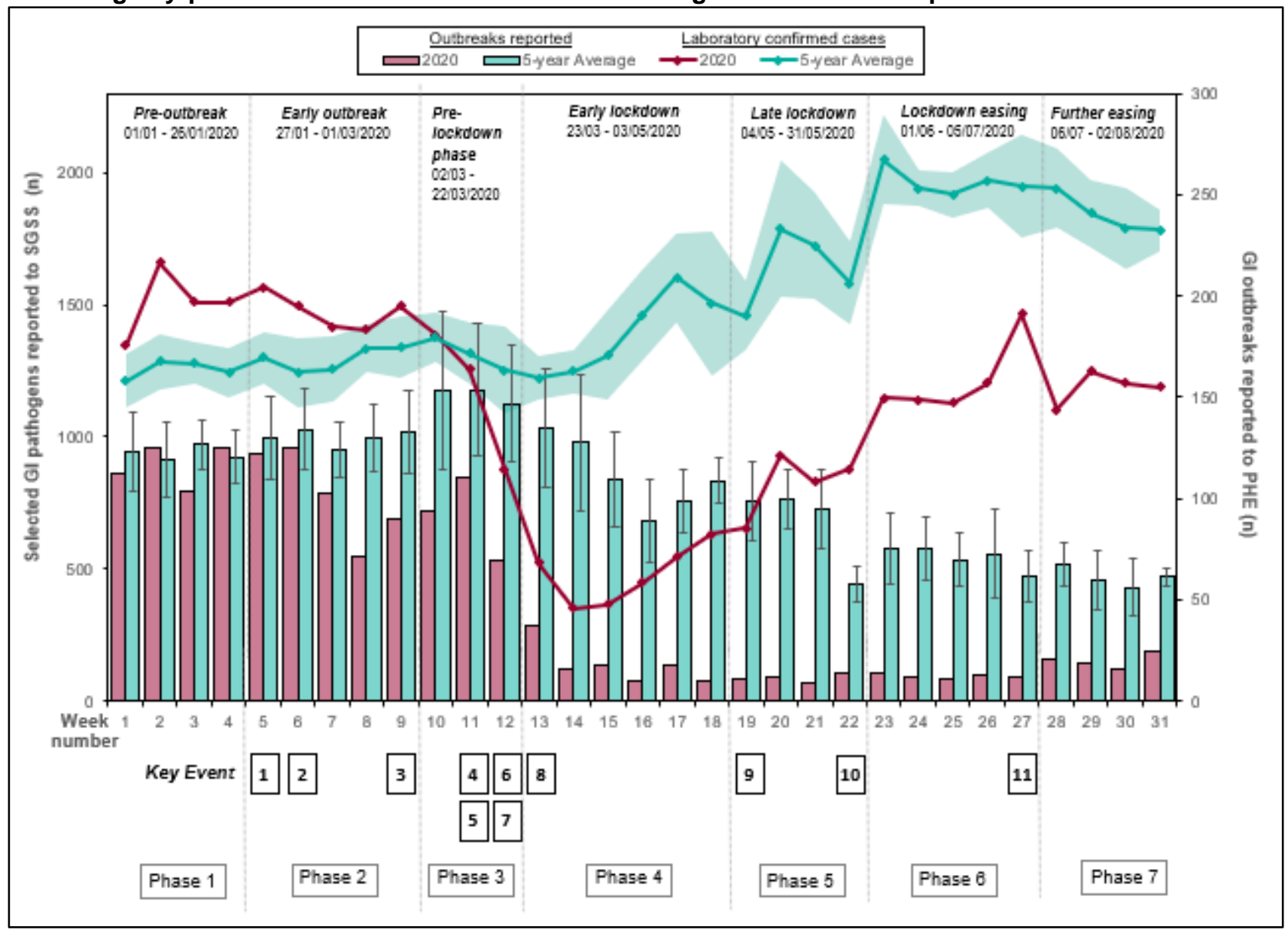

$\underline{\text { Key Events }}$

\begin{tabular}{|c|l|}
\hline 1 & $\begin{array}{l}\text { First imported cases confirmed in England } \\
(31 / 01 / 2020)\end{array}$ \\
\hline 2 & $\begin{array}{l}\text { Public Health information campaign launched } \\
(03 / 02 / 2020)\end{array}$ \\
\hline 3 & $\begin{array}{l}\text { First evidence of community transmission in } \\
\text { the UK (26/02/2020) }\end{array}$ \\
\hline 4 & WHO declares global pandemic (11/03/2020) \\
\hline 5 & $\begin{array}{l}\text { UK moves from contain to delay phase of } \\
\text { outbreak (12/03/2020) }\end{array}$ \\
\hline 6 & $\begin{array}{l}\text { Social distancing introduced. Vulnerable } \\
\text { individuals asked to self -isolate. Public asked } \\
\text { to avoid non-essential travel and work from } \\
\text { home (16/03/2020) }\end{array}$ \\
\hline
\end{tabular}

\begin{tabular}{|l|l|}
\hline 7 & $\begin{array}{l}\text { School closures. Furlough scheme } \\
\text { announced. Restaurants, entertainment } \\
\text { and leisure venues closed (20/03/2020) }\end{array}$ \\
\hline 8 & $\begin{array}{l}\text { UK wide partial lockdown implemented } \\
(23 / 03 / 2020)\end{array}$ \\
\hline 9 & $\begin{array}{l}\text { Announcement on partial easing of } \\
\text { lockdown measures. Workers encouraged } \\
\text { to return to work if unable to work from } \\
\text { home (10/05/2020) }\end{array}$ \\
\hline 10 & $\begin{array}{l}\text { National testing and contact tracing } \\
\text { programme begins (28/05/2020) }\end{array}$ \\
\hline 11 & $\begin{array}{l}\text { Pubs and restaurants reopen for dine-in } \\
\text { customers (04/07/2020) }\end{array}$ \\
\hline
\end{tabular}


medRxiv preprint doi: https://doi.org/10.1101/2021.04.06.21254174; this version posted April 8, 2021. The copyright holder for this preprint (which was not certified by peer review) is the author/funder, who has granted medRxiv a license to display the preprint in perpetuity.

Figure 2 - Laboratory confirmed All righ pathod No reuse allowed withoutpermissian reported to England between Week 1 and Week 312020 and the 5-year weekly average (95\% confidence interval), by COVID-19 outbreak Phase
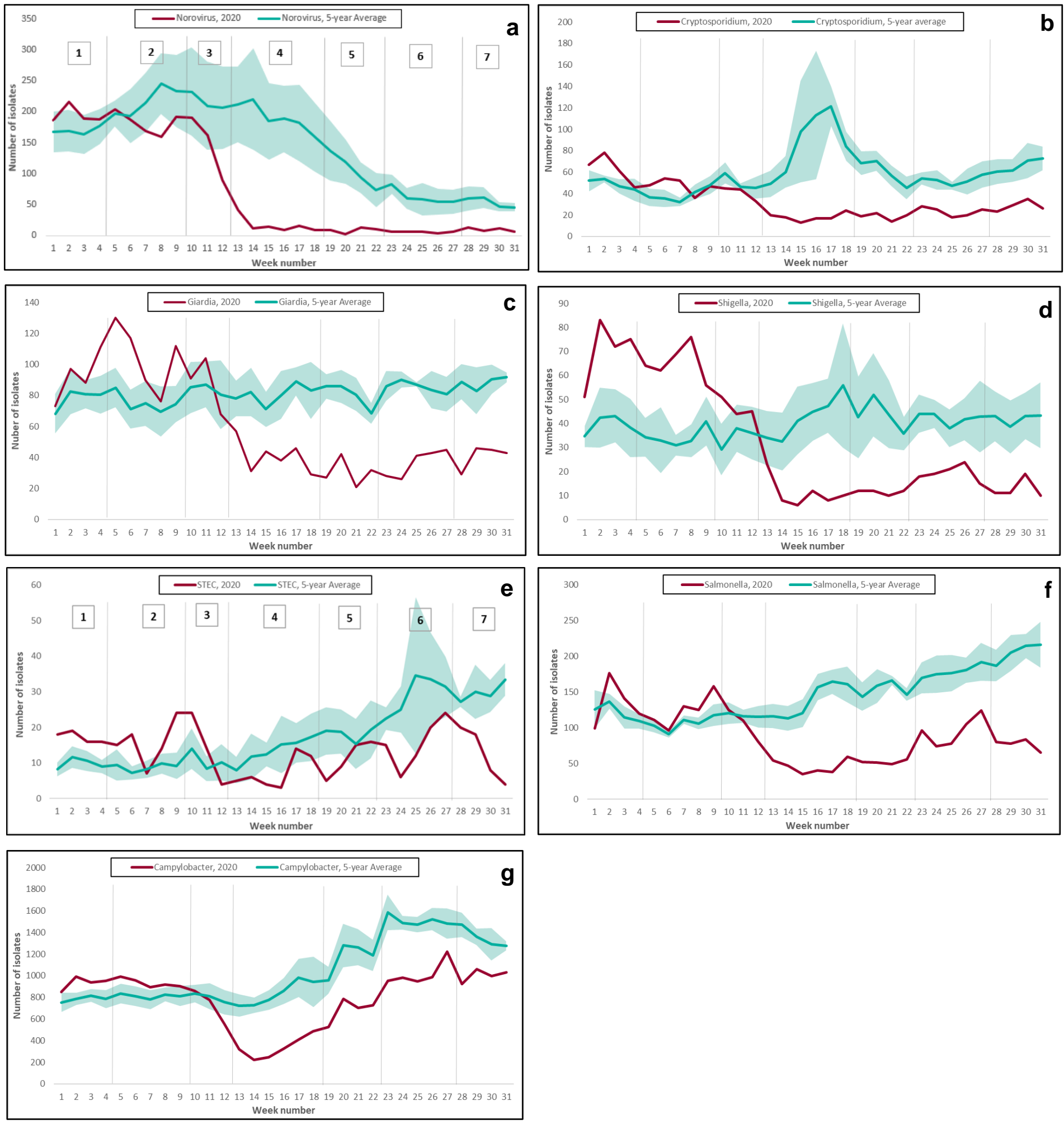
medRxiv preprint doi: https://doi.org/10.1101/2021.04.06.21254174; this version posted April 8, 2021. The copyright holder for this preprint (which was not certified by peer review) is the author/funder, who has granted medRxiv a license to display the preprint in perpetuity.

Figure 3 - Laboratory confirmed All right pathed Nogeuse allowed without permissipn. Health England between Week 1 and Week 312020 and the 5-year weekly average (95\% confidence interval), by COVID19 outbreak Phase and age group
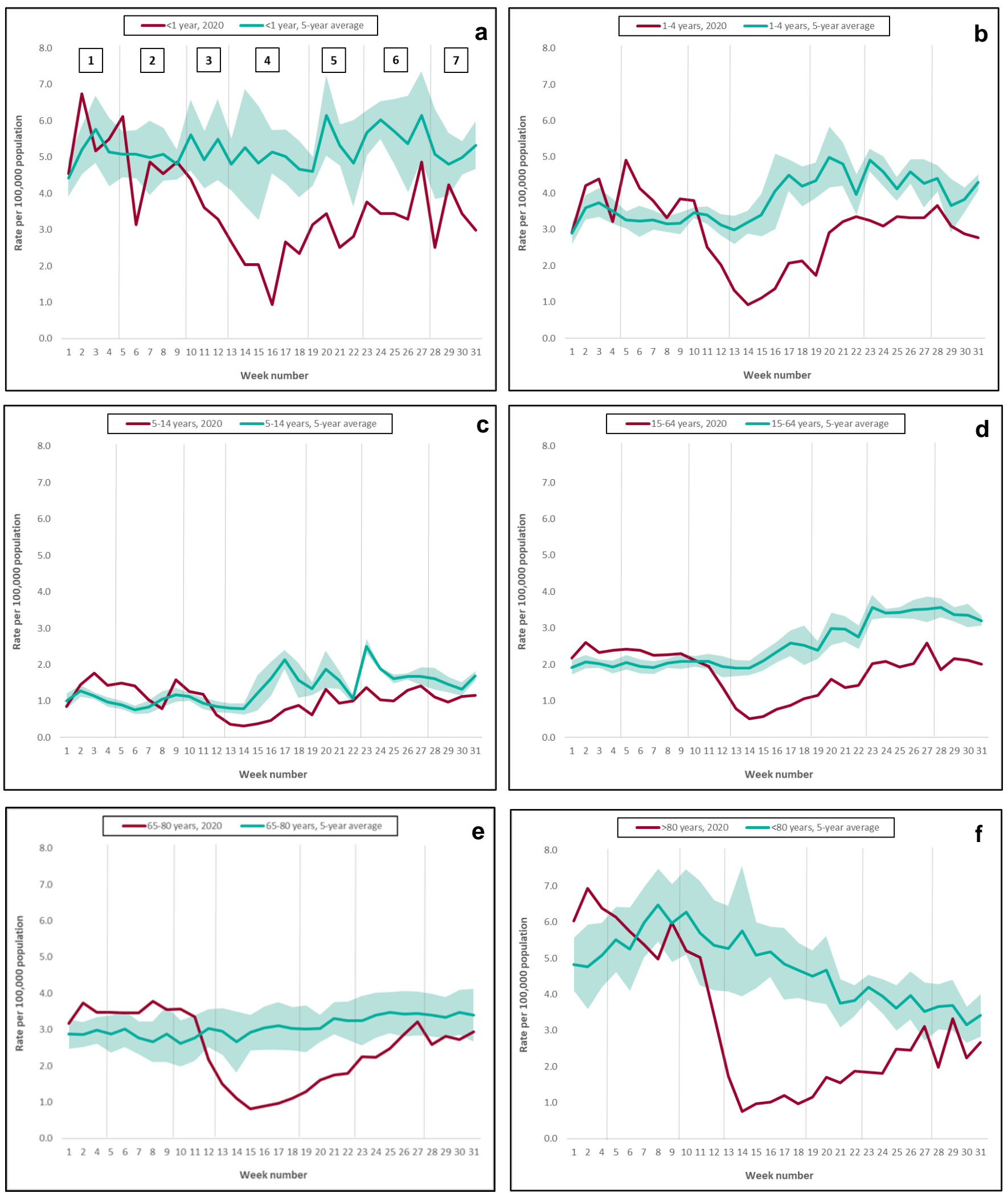
Figure 4 - Laboratory confirmed GI cases by PHE region and COVID-19 outbreak Phase, percentage change compared to the 5-year average for the region

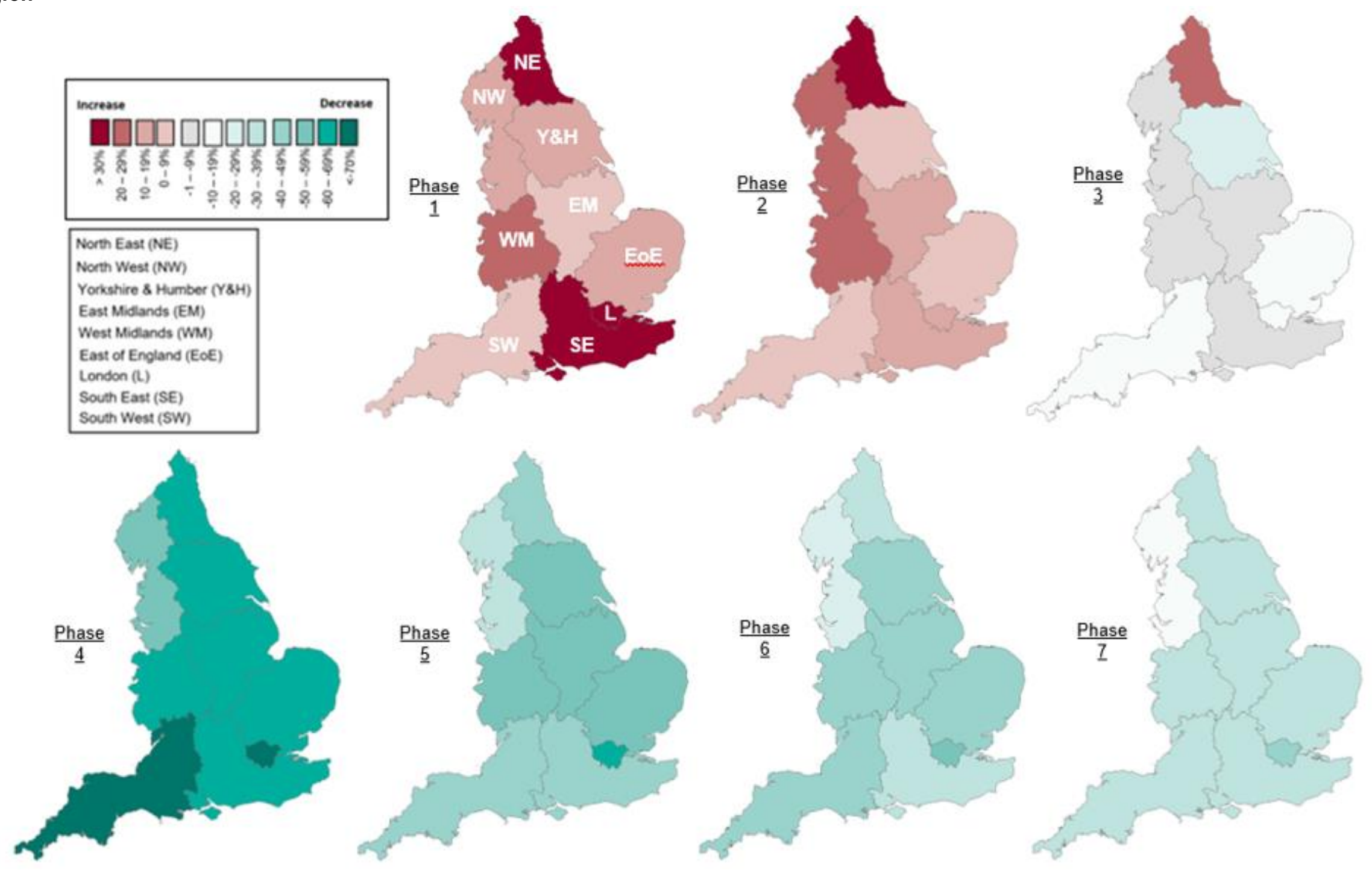


Figure 5 - Syndromic indicators for Phases 1-7 of the COVID-19 response, 2020 and 2019
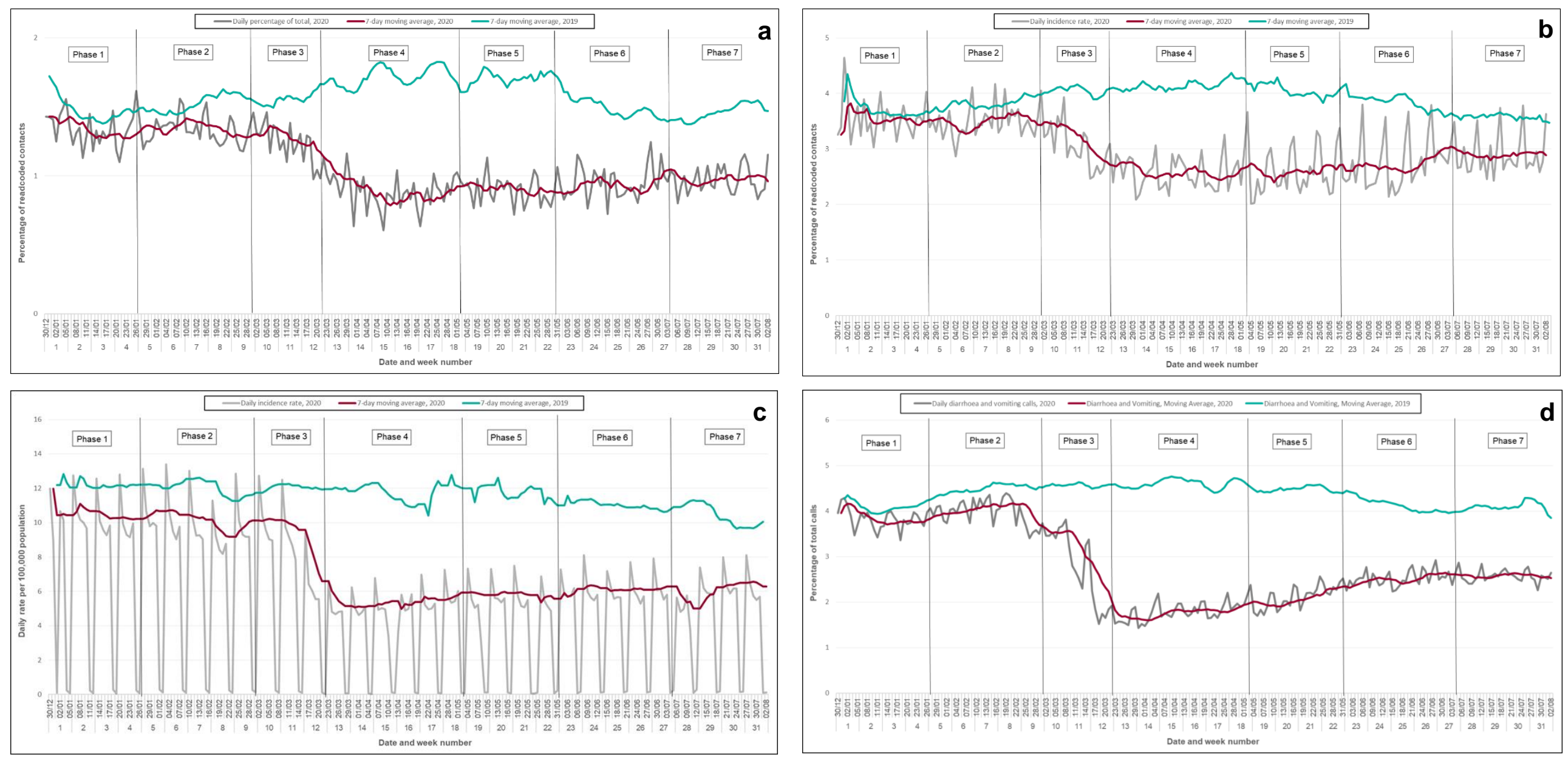
medRxiv preprint doi: https://doi.org/10.1101/2021.04.06.21254174; this version posted April 8, 2021. The copyright holder for this preprint (which was not certified by peer review) is the author/funder, who has granted medRxiv a license to display the preprint in perpetuity.

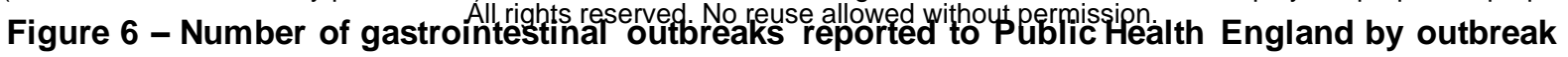
setting between Phases 1 and 7 of the COVID-19 response, with the lower bound ${ }^{\star}$ of the 5 -year average $95 \%$ confidence interval indicated by diamonds

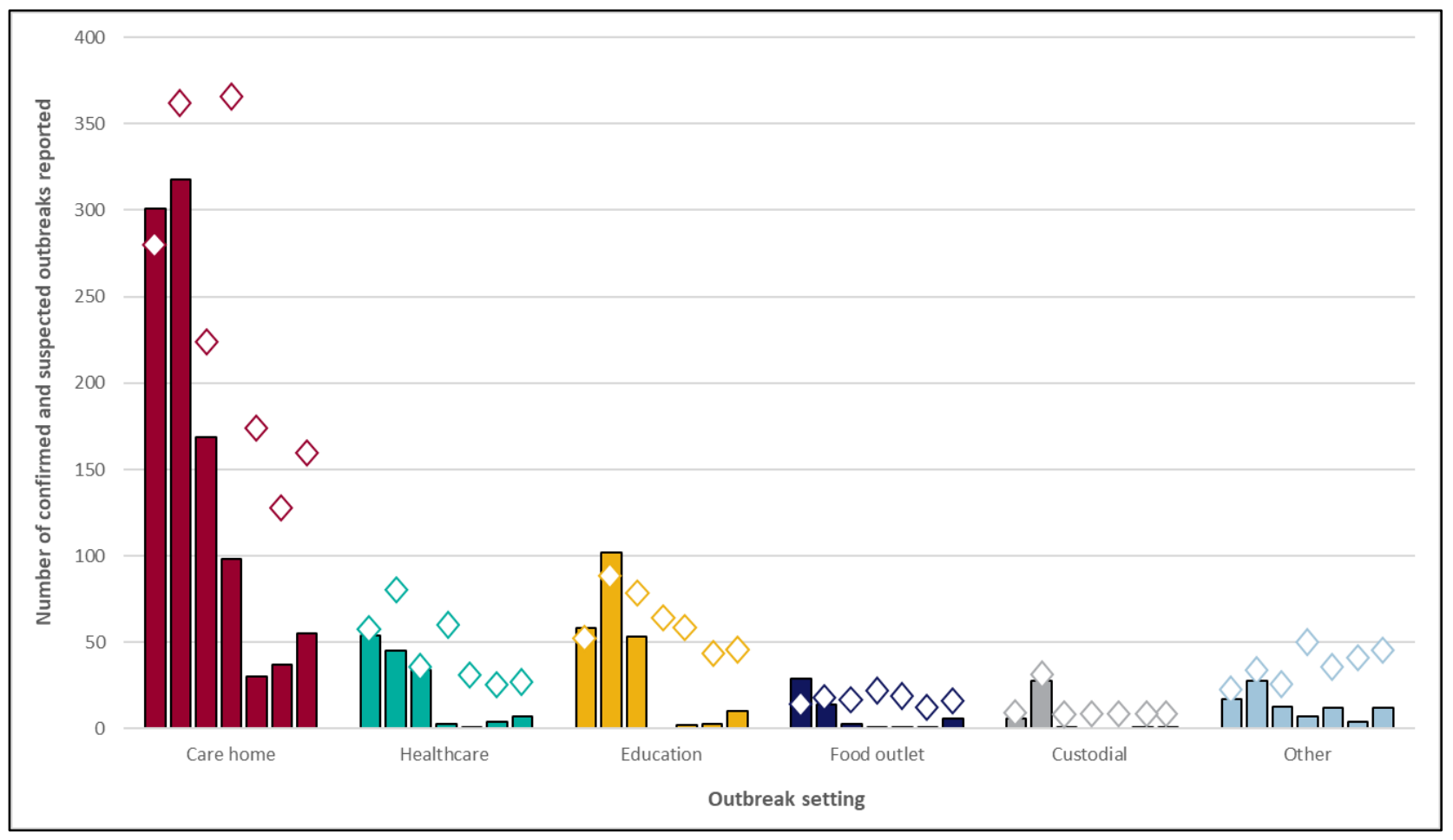


medRxiv preprint doi: https://doi.org/10.1101/2021.04.06.21254174; this version posted April 8, 2021. The copyright holder for this preprint (which was not certified by peer review) is the author/funder, who has granted medRxiv a license to display the preprint in perpetuity.

Table 2 - Exposures reportedll inghts resserved No reuse allowed without permissifin ince questionnaires* for GI pathogens, North East residents. Phase 2 - Phase 7 of the COVID-19 outbreak

\begin{tabular}{|c|c|c|c|c|c|c|c|c|}
\hline \multirow{2}{*}{\multicolumn{2}{|c|}{ Exposure category }} & \multicolumn{2}{|c|}{ Current cases (2020) } & \multicolumn{2}{|c|}{ Historic cases (2015-2019) } & \multirow[b]{2}{*}{$\begin{array}{l}\text { Odds } \\
\text { ratio }\end{array}$} & \multirow{3}{*}{$\frac{95 \% \mathrm{Cl}}{[0.23-0.57]}$} & \multirow{3}{*}{$\begin{array}{l}P \text { value } \\
<0.001\end{array}$} \\
\hline & & Exposed & Unexposed & Exposed & Unexposed & & & \\
\hline \multirow{10}{*}{ All Gl organisms } & Foreign Travel & 25 & 133 & 590 & 1151 & 0.37 & & \\
\hline & Visitor Attraction & 3 & 130 & 106 & 1045 & 0.23 & {$[0.05-0.70]$} & 0.006 \\
\hline & Water Exposure & 22 & 111 & 293 & 858 & 0.58 & [0.34-0.94] & 0.024 \\
\hline & Food Outlet & 94 & 39 & 898 & 253 & 0.68 & [0.45-1.04] & 0.056 \\
\hline & Contact & 24 & 109 & 269 & 882 & 0.72 & {$[0.43-1.16]$} & 0.166 \\
\hline & Rural Environment & 12 & 121 & 84 & 1067 & 1.26 & [0.61-2.40] & 0.474 \\
\hline & Travel (UK) & 17 & 116 & 173 & 978 & 0.83 & {$[0.46-1.43]$} & 0.489 \\
\hline & Animal Contact & 82 & 51 & 744 & 407 & 0.88 & {$[0.60-1.30]$} & 0.496 \\
\hline & Social and Leisure & 15 & 118 & 119 & 1032 & 1.10 & {$[0.58-1.97]$} & 0.737 \\
\hline & Sports and Leisure & 2 & 131 & 14 & 1137 & 1.24 & [0.14-5.49] & 0.777 \\
\hline \multirow{10}{*}{ Cryptosporidium } & Foreign Travel & 23 & 0 & 384 & 71 & 0.00 & {$[0.00-0.74]$} & 0.023 \\
\hline & Food Outlet & 23 & 13 & 313 & 239 & 0.40 & [0.16-1.07] & 0.034 \\
\hline & Contact & 23 & 10 & 313 & 79 & 2.28 & [0.86-5.86] & 0.056 \\
\hline & Visitor Attraction & 23 & 2 & 313 & 63 & 0.38 & [0.04-1.62] & 0.18 \\
\hline & Animal Contact & 23 & 16 & 313 & 253 & 0.54 & {$[0.20-1.63]$} & 0.192 \\
\hline & \begin{tabular}{|l|} 
Travel (UK) \\
\end{tabular} & 23 & 6 & 313 & 52 & 1.77 & [0.54-4.99] & 0.246 \\
\hline & Sports and Leisure & 23 & 0 & 313 & 6 & 0 & {$[0.00-8.90]$} & 0.503 \\
\hline & Water Exposure & 23 & 9 & 313 & 141 & 0.78 & [0.29-2.01] & 0.582 \\
\hline & Rural Environment & 23 & 4 & 313 & 45 & 1.25 & [0.30-4.02] & 0.693 \\
\hline & Social and Leisure & 23 & 2 & 313 & 25 & 1.1 & [0.12-4.94] & 0.904 \\
\hline \multirow{9}{*}{ STEC } & Visitor Attraction & 21 & 0 & 70 & 10 & 0.00 & [0.00-1.15] & 0.066 \\
\hline & Social and Leisure & 21 & 2 & 70 & 19 & 0.28 & [0.03-1.38] & 0.093 \\
\hline & \begin{tabular}{|l|} 
Foreign Travel \\
\end{tabular} & 23 & 2 & 92 & 22 & 0.30 & [0.03-1.42] & 0.108 \\
\hline & Contact & 21 & 3 & 70 & 19 & 0.45 & [0.08-1.81] & 0.227 \\
\hline & Animal Contact & 21 & 3 & 70 & 19 & 0.45 & [0.08-1.81] & 0.227 \\
\hline & Travel (UK) & 21 & 3 & 70 & 16 & 0.56 & {$[0.09-2.32]$} & 0.397 \\
\hline & Water Exposure & 21 & 6 & 70 & 25 & 0.72 & [0.20-2.29] & 0.545 \\
\hline & Rural Environment & 21 & 3 & 70 & 8 & 1.29 & {$[0.20-6.12]$} & 0.725 \\
\hline & Food Outlet & 21 & 18 & 70 & 58 & 1.24 & [0.29-7.59] & 0.757 \\
\hline \multirow{10}{*}{ Giardia } & Water Exposure & 29 & 6 & 318 & 113 & 35.53 & [0.15-1.24] & 0.107 \\
\hline & Foreign Travel & 35 & 6 & 438 & 120 & 0.55 & [0.18-1.39] & 0.187 \\
\hline & Animal Contact & 29 & 16 & 318 & 206 & 64.78 & [0.29-1.57] & 0.302 \\
\hline & Contact & 29 & 3 & 318 & 53 & 16.67 & [0.11-1.99] & 0.376 \\
\hline & Travel (UK) & 29 & 4 & 318 & 64 & 20.13 & [0.16-1.94] & 0.411 \\
\hline & Visitor Attraction & 29 & 1 & 318 & 22 & 6.92 & [0.01-3.22] & 0.472 \\
\hline & Sports and Leisure & 29 & 0 & 318 & 4 & 1.26 & {$[0.00-10.77]$} & 0.544 \\
\hline & Food Outlet & 29 & 20 & 318 & 232 & 72.96 & {$[0.34-2.14]$} & 0.645 \\
\hline & Rural Environment & 29 & 3 & 318 & 28 & 8.81 & {$[0.22-4.29]$} & 0.781 \\
\hline & Social and Leisure & 29 & 1 & 318 & 11 & 3.46 & {$[0.02-7.34]$} & 0.998 \\
\hline \multirow{9}{*}{ Salmonella } & Foreign Travel & 65 & 14 & 739 & 335 & 45.33 & {$[0.17-0.62]$} & $<0.001$ \\
\hline & Food Outlet & 51 & 35 & 404 & 329 & 0.50 & {$[0.25-1.02]$} & 0.031 \\
\hline & Rural Environment & 51 & 2 & 404 & 3 & 5.46 & [0.44-48.53] & 0.040 \\
\hline & Contact & 51 & 7 & 404 & 99 & 0.49 & {$[0.18-1.15]$} & 0.086 \\
\hline & Visitor Attraction & 51 & 0 & 404 & 7 & 0.00 & [0.00-4.35] & 0.343 \\
\hline & Animal Contact & 51 & 33 & 404 & 234 & 1.33 & {$[0.70-2.60]$} & 0.354 \\
\hline & Water Exposure & 51 & 0 & 404 & 5 & 0.00 & [0.00-6.13] & 0.424 \\
\hline & Travel (UK) & 51 & 3 & 404 & 35 & 0.66 & [0.13-2.22] & 0.499 \\
\hline & Social and Leisure & 51 & 9 & 404 & 61 & 1.2 & [0.49-2.68] & 0.635 \\
\hline \multirow{9}{*}{ Shigella } & Contact & 9 & 1 & 46 & 19 & 0.18 & [0.00-1.55] & 0.085 \\
\hline & Sports and Leisure & 9 & 2 & 46 & 3 & 4.10 & [0.28-41.60] & 0.134 \\
\hline & Foreign Travel & 12 & 3 & 88 & 42 & 47.73 & {$[0.06-1.61]$} & 0.138 \\
\hline & Visitor Attraction & 9 & 0 & 46 & 4 & 0.00 & {$[0.00-5.04]$} & 0.358 \\
\hline & Water Exposure & 9 & 1 & 46 & 9 & 0.51 & [0.01-4.83] & 0.548 \\
\hline & Social and Leisure & 9 & 1 & 46 & 3 & 1.79 & [0.03-25.55] & 0.628 \\
\hline & Food Outlet & 9 & 8 & 46 & 40 & 1.20 & [0.12-62.00] & 0.874 \\
\hline & Travel (UK) & 9 & 1 & 46 & 6 & 0.83 & {$[0.02-8.57]$} & 0.874 \\
\hline & Animal Contact & 9 & 1 & 46 & 5 & 1.02 & [0.02-11.19] & 0.983 \\
\hline
\end{tabular}

*Questionnaires for Cryptosporidium sp, Giardia lamblia, giardia, STEC. Salmonella sp and Shigella sp $\neq$ Cases reporting foreign travel exposure were excluded from the analysis of all other exposure categories 